\title{
Exhaled nitric oxide among pulpmill workers reporting gassing incidents involving ozone and chlorine dioxide
}

\author{
A-C. Olin*, G. Ljungkvist*, B. Bake**, S. Hagberg*, L. Henriksson*, K. Torén*,+
}

Exhaled nitric oxide among pulpmill workers reporting gassing incidents involving ozone and chlorine dioxide. A-C. Olin, G. Ljungkvist, B. Bake, S. Hagberg, L. Henriksson, K. Torén. (C) ERS Journals Ltd 1999.

ABSTRACT: The aim of the study was to investigate whether measurement of nitric oxide in exhaled air could be used for assessing the effects of irritants on the respiratory system, in this case recurrent ozone gassing in an occupational setting.

The study population comprised bleachery workers $(n=56)$ from a Swedish pulpmill carrying out ozone-based pulp bleaching since 1992 and controls $(n=39)$. Both groups were investigated by measuring NO in exhaled air, methacholine challenge test and answers to a questionnaire concerning history of respiratory symptoms and accidental exposure to ozone peaks.

There was no significant difference in NO output between exposed subjects and controls (median 67.2 versus $55.0 \mathrm{~nL} \cdot \min ^{-1}, \mathrm{p}=\mathbf{0 . 6 4}$ ). However, among bleachery workers reporting ozone gassings, the median NO output was $90.0 \mathrm{~nL} \cdot \mathrm{min}^{-1}$ compared to $58.8 \mathrm{~nL} \cdot \mathrm{min}^{-1}$ among those not reporting such incidents $(p=0.019)$. There was no relation between exhaled NO and the prevalence of respiratory symptoms or bronchial hyperresponsiveness. In a multiple regression model, only reported ozone gassings were associated $(p=0.016)$ with NO output.

The results indicate an association between previous response to ozone gassing and nitric oxide output. The increased nitric oxide output among the bleachery workers reporting peak ozone exposure may indicate that chronic airway inflammation is present. Further studies are needed to evaluate the extent to which nitric oxide can be used for biological monitoring of respiratory health effects, and to relate it to other markers of airway inflammation.

Eur Respir J 1999; 14: 828-831.

Nitric oxide levels in exhaled air have been proposed as a biomarker of airway inflammation [1]. NO can be detected at low concentration in exhaled air from healthy individuals. Increased levels of exhaled NO have been found in asthmatics [2], during upper respiratory tract infections [3] and in patients with bronchiectases [4]. Exhaled NO concentrations have been found to be lower in smokers [4]. Very high concentrations, $>20,000$ parts per billion (ppb) have been detected in human paranasal sinuses [4].

Pulpmill workers can be exposed to a wide variety of irritant gases, and some epidemiological studies have shown that such workers, especially those in bleacheries, are subject to an increased prevalence of respiratory symptoms and decreased pulmonary function [5-8]. A succession of gassing events seems to be a major risk factor in these groups. In 1992, ozone was introduced as a bleaching agent in the Swedish pulp industry [9]. Process disturbances caused bleachery workers to be accidentally exposed to high peak concentrations of ozone $(>10,000 \mathrm{ppb})$.

Ozone is a well-known respiratory irritant, and acute inhalations have been shown to cause damage to epithelial cells in the airway [10]. Alveolar and interstitial macrophages from rats exposed to ozone (1-2 ppm for $3 \mathrm{~h}$ ) showed increased NO production, and, especially in the alveolar macrophages, increased expression of inducible NO synthase (iNOS) was found [11]. Exposure to oxidants has also been shown to induce iNOS messenger ribonucleic acid (mRNA) in human epithelial cells in vitro [12]
*Sections of Occupational and Environmental Medicine, **Clinical Physiology, ${ }^{+}$Respiratory Medicine and Allergology, Sahlgrenska University Hospital, Gothenburg, Sweden.

Correspondence: A-C. Olin

Section of Occupational and Environmental Medicine

Sahlgrenska University Hospital

St. Sigfridsgatan

85B S-412 66

Göteborg Sweden

Fax: 4631409728

Keywords: Airway inflammation

nitric oxide

occupational ozone

Received: December 91998

Accepted after revision May 181999

This study was supported by the Swedish Council for Worklife Research and by the Torsten and Ragnar Söderbergs Foundation.

The present study aimed to investigate whether NO concentrations in exhaled air could be used for the biological monitoring of respiratory health effects due to ozone exposure among bleachery workers, especially among those experiencing gassing events.

\section{Subjects and methods}

All process and maintenance workers $(n=61)$ in the bleaching department of a sulphate-based pulpmill were selected as exposed subjects. The mill had been using chlorine dioxide as a bleaching agent since the 1950s. In 1992, this was replaced by ozone, but chlorine dioxide was periodically used until 1995 . All 50 process workers from an adjacent paper mill were recruited as controls. That mill produced printing paper, and the controls were exposed to low levels of paper dust. Eleven controls were excluded for a variety of reasons: respiratory infection with fever $(n=1)$, current ozone exposure $(n=1)$, vacation $(n=4)$, and refusal to participate $(n=5)$. Five exposed subjects refused to participate. In all, 56 exposed subjects and 39 controls were included in the final study.

All subjects received a questionnaire with items from previous questionnaires [13]. Exposed and unexposed workers were examined in random order. They were asked about current respiratory infections, current smoking and use of drugs.

Exhaled NO was measured using a chemiluminescence analyser (Monitor Labs 9841; Monitor Labs, Englewood, 
Table 1. - Characteristics of the exposed subjects and unexposed controls

\begin{tabular}{lcc}
\hline & Exposed & Unexposed \\
\hline Subjects n & 56 & 39 \\
Age yrs* & $42.3 \pm 10.1$ & $45.6 \pm 8.5$ \\
Male/Female n & $51 / 5$ & $32 / 7$ \\
Smokers n (\%) & $10(18)$ & $7(18)$ \\
Exsmokers n (\%) & $13(24)$ & $11(28)$ \\
Never smokers n (\%) & $33(58)$ & $21(54)$ \\
Employment duration yrs* & $17.0 \pm 10.9$ & $20.8 \pm 7.8$ \\
\hline
\end{tabular}

*: mean \pm SD.

$\mathrm{CO}$, USA) with a detection limit of $0.5 \mathrm{~nL} \cdot \mathrm{L}^{-1}(\mathrm{ppb})$. It was calibrated before and after the field measurements using a certified gas mixture in a dynamic dilution system. Each subject was seated wearing a noseclip and breathed NOfree breathing air with normal tidal breathing for $4 \mathrm{~min}$ [14]. None had smoked within $30 \mathrm{~min}$ prior to the measurement. The analyser continuously sampled exhaled air $\left(0.64 \mathrm{~L} \cdot \mathrm{min}^{-1}\right)$ via Teflon ${ }^{\mathrm{R}}$ tubing, reaching a plateau level of NO after 3 min of sampling. The total volume of exhaled air was measured during the 4th minute, at the end of which the concentration of NO was registered. NO levels were expressed as NO output $\left(\mathrm{nL} \cdot \mathrm{min}^{-1}\right)$ i.e. concentration $\left(\mathrm{nL} \cdot \mathrm{L}^{-1}\right) \times$ volume exhaled in $1 \mathrm{~min}$. The NO concentration in indoor air was determined before each measurement. There was no correlation between NO output and ambient NO concentrations.

The method was tested on two different occasions separated by 2 weeks on 29 persons. The coefficient of variation of NO output was $29 \%$.

All subjects underwent spirometry and a methacholine challenge test (MCT) according to published guidelines [15]. The subjects performed at least three technically acceptable trials and the largest forced vital capacity (FVC) or vital capacity (VC) and forced expiratory volume in one second (FEV1) were registered and compared with predicted values [16]. Briefly, the MCT commenced with the inhalation of saline diluent, and the first technically acceptable post-diluent FEV1 recorded 2 min later was used as the control value. The methacholine was delivered using doubling concentrations starting at $0.5 \mathrm{mg} \cdot \mathrm{mL}^{-1}$ and stopping at $32 \mathrm{mg} \cdot \mathrm{mL}^{-1}$, if the provocative concentration of methacholine causing a 20\% fall in FEV1 PC20 had not been reached earlier. Subjects with known asthma or respiratory symptoms started at a methacholine concentration

Table 2. - Median nitric oxide output of ozone-exposed pulpmill workers and unexposed controls in relation to ozone exposure and ozone peaks

\begin{tabular}{lccc}
\hline & $\begin{array}{c}\text { Subjects } \\
\mathrm{n}\end{array}$ & $\begin{array}{c}\text { NO output } \\
\mathrm{nL} \cdot \mathrm{min}^{-1}\end{array}$ & p-value* \\
\hline $\begin{array}{c}\text { Unexposed controls } \\
\text { Exposed subjects }\end{array}$ & 39 & 55.0 & \\
$\begin{array}{c}\text { Exposed without } \\
\text { ozone gassing }\end{array}$ & 56 & 67.2 & $0.64^{\#}$ \\
$\begin{array}{c}\text { Exposed with } \\
\text { ozone gassings }\end{array}$ & 24 & 58.8 & \\
\hline
\end{tabular}

*: Kruskall-Wallis test; ${ }^{+}$: Three exposed subjects did not answer the question about ozone gassings; their NO output was 83.2 $\mathrm{nL} \cdot \mathrm{min}^{-1}$; ${ }^{\#}$ : exposed versus unexposed; ${ }^{\S}$ : exposed with ozone gassings versus exposed without ozone gassing. of $0.125 \mathrm{mg} \cdot \mathrm{mL}^{-1}$. Two different cut-off points were used, $\mathrm{PC} 204 \mathrm{mg} \cdot \mathrm{mL}^{-1}$ and $\mathrm{PC} 20 \leq 32 \mathrm{mg} \cdot \mathrm{mL}^{-1}$. Atopy was assessed by means of Phadiatope ${ }^{\mathrm{TM}}$ (Pharmacia\&Upjohn Diagnostics, Uppsala, Sweden) [17]. Class 0 was regarded as negative and class 1 as positive (atopic). The characteristics of the subjects are presented in table 1 .

\section{Exposure}

Under normal conditions, the concentration of ozone in a pulpmill is low. During accidents and technical hitches, however, stationary measurements at similar mills to the one in question have indicated ozone peaks $>900 \mathrm{ppb}$. Similar process disturbances have also occurred at that mill, but no objective air-monitoring data were available to quantify the amplitude of the ozone peaks.

In the questionnaire the following exposure-related questions were put to the subjects. 1. "Have you been exposed to ozone with coughing, wheezing, breathlessness or pain in thorax as a result?" 2. "Have you been exposed to chlorine dioxide with coughing, breathlessness or wheezing as a result?" "Ozone gassing" was defined as a positive response to question 1 , and "chlorine dioxide gassing" as a positive response to question 2 .

\section{Statistical methods}

The statistical analyses of the basic data from the subjects were based on Student's test and the Chi-squared test; otherwise, a nonparametric method (Wilcoxon) was used, and $p$-values were determined. Trends were analysed using the Kruskal-Wallis test and correlations tested using Spearman's rank correlation coefficient. The NO data were not normally distributed; hence, the medians are reported. The associations between the log transformed values of $\mathrm{NO}$ output and different explanatory variables (smoking, atopy, sex, age and chlorine dioxide gassings) were tested using multiple linear regression, and the significance of the slope in the multivariate regression model was based on the t-distribution. For the linear regression models, PROC REG from the SAS statistical package (release 6.12; Cary, NC, USA) was used.

\section{Results}

There was no significant difference in median NO output between exposed subjects and unexposed controls (table 2). However, among the exposed subjects, those reporting ozone gassings had a higher median NO output than those who did not report such gassings. Among the exposed subjects, the reported number of years of exposure to ozone gassings was positively associated with the amount of exhaled NO, $\mathrm{p}=0.048$ (fig. 1).

In workers reporting chlorine dioxide gassings, the median NO output was $84 \mathrm{~nL} \cdot \mathrm{min}^{-1}$ compared to $52.0 \mathrm{~nL} \cdot \mathrm{min}^{-1}$ for those not reporting such gassings $(p=0.06)$. The NO output of the 15 workers reporting gassings of both chlorine dioxide and ozone was $94.8 \mathrm{~nL} \cdot \mathrm{min}^{-1}(\mathrm{p}=0.004)$.

No significant differences in median NO output were found with regard to smoking habits (smokers, 51.6 $\mathrm{nL} \cdot \mathrm{min}^{-1}$; exsmokers $64.5 \mathrm{~nL} \cdot \mathrm{min}^{-1}$; neversmokers 66.0 $\mathrm{nL} \cdot \mathrm{min}^{-1}(\mathrm{p}=0.15$, smokers versus nonsmokers). The NO output among atopics was $66.1 \mathrm{~nL} \cdot \mathrm{min}^{-1}$ compared to 58.3 $\mathrm{nL} \cdot \mathrm{min}^{-1}$ for non-atopics $(\mathrm{p}=0.22)$.

There were only small differences in NO output between those reporting and those not reporting respiratory 


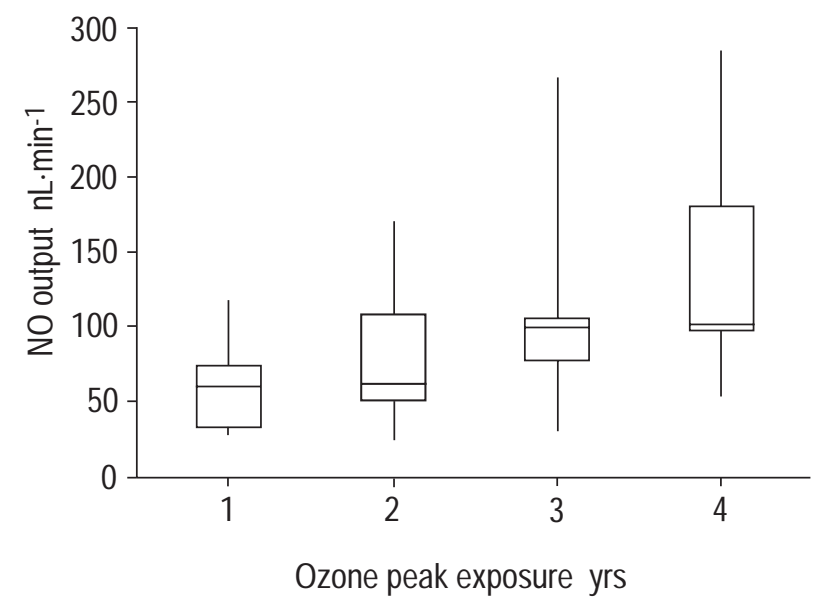

Fig. 1 - Box plot of nitric oxide output according to number of years of exposure to ozone peaks. Medians and 25th and 75th percentiles are shown. The vertical bars represent the 5 th and 95 th percentiles $(\mathrm{p}=0.048$ (Kruskal-Wallis test for trend))

symptoms (cough, wheezing or nasal symptoms). No relationship was found between $\mathrm{NO}$ output and $\mathrm{PC} 20\left(\mathrm{r}_{\mathrm{s}}=\right.$ $-0.06, p=0.66)$ in the whole group. Among those with asthma or wheezing the correlation was stronger $\left(\mathrm{r}_{\mathrm{s}}=-0.54\right.$, $\mathrm{p}=0.11$ ). Three exposed subjects reported doctor-diagnosed asthma, with a median NO output of $73 \mathrm{~nL} \cdot \mathrm{min}^{-1}$, as did one control, with a NO output of $56 \mathrm{~nL} \cdot \mathrm{min}^{-1}$. Three of them were using inhaled glucocorticoids.

Altogether eight subjects used either inhaled or oral glucocorticoids regularly. Their median NO output was 91 $\mathrm{nL} \cdot \mathrm{min}^{-1}$ compared to $61 \mathrm{~nL} \cdot \mathrm{min}^{-1}$ among those not reporting use of steroid medication.

The exposed subjects had significantly lower FEV1 than controls (table 3). There was no statistically significant difference with regard to FVC. Among the exposed, no statistically significant differences in FEV1 and FVC were found in relation to reported ozone gassings. The exposed subjects reported more wheezing than did the controls (23 versus $8 \%, \mathrm{p}=0.04)$, but reported gassings of ozone or chlorine dioxide were not significantly related to wheeze.

The only statistically significant association $(\mathrm{p}<0.01)$ with the amount of exhaled NO that was revealed in a multiple regression model was that of "ozone gassings" (table 4).

Table 3. - Lung function measurements and atopy in exposed subjects and unexposed controls

\begin{tabular}{|c|c|c|c|}
\hline & Exposed* & Unexposed* & p-value \\
\hline Subjects n & 56 & 39 & \\
\hline FVC \% $\%$ pred $^{\S}$ & $95.2 \pm 12.9$ & $98.9 \pm 10.6$ & $0.22^{+}$ \\
\hline FEV1 \% pred $\S$ & $97.6 \pm 14.6$ & $104.0 \pm 9.4$ & $0.007^{+}$ \\
\hline $\mathrm{PC} 20<4 \mathrm{mg} \cdot \mathrm{mL}^{-1} \mathrm{n}(\%)$ & $14(25)$ & $7(20)$ & $0.55^{\#}$ \\
\hline $\mathrm{PC}_{20}<32 \mathrm{mg} \cdot \mathrm{mL}^{-1} \mathrm{n}(\%)$ & $33(60)$ & $16(46)$ & $0.19^{\#}$ \\
\hline Positive Phadiatope $^{\mathrm{TM}}$ n (\%) & $16(29)$ & $9(23)$ & \\
\hline
\end{tabular}

*: 35 exposed subjects and 55 unexposed controls underwent spirometry and a metacholine challenge test ${ }^{\S}:$ mean $\pm \mathrm{SD} ;{ }^{+}: \mathrm{t}$-test; \#: Chi-squared test. FVC: forced vital capacity; FEV1: forced expiratory volume in one second; $\mathrm{PC} 20$ : provocative concentration of methacholine causing a $20 \%$ fall in FEV1.

\section{Discussion}

This study indicates that NO concentrations in exhaled air are increased among workers accidentally exposed to high levels of ozone and chlorine dioxide. One could hypothesize that the exposure causes airway inflammation and a concomitant increase in $\mathrm{NO}$ output.

The major limitation of the study design is that the method used for measuring NO allows contamination of the exhaled air by air derived from the upper respiratory tract [18]. In another study, using the same method, it has been shown that $\sim 30 \%$ of the variability in exhaled NO levels was explained by contribution from the upper airways [14].

Since humans are predominantly nose breathers, the nose and its cell lines are among the first to come in contact with ozone, and ozone-exposed humans have been shown to have signs of both nasal inflammation and inflammation of the lower respiratory tract $[19,20]$. Hence, from the present data it is not possible to state whether the increased NO originates from the upper or lower airways.

The European Respiratory Society Task Force "Measurement of Nitric Oxide in Exhaled Air" proposed, in 1997, a slow single exhalation as standard for measuring exhaled NO [21]. This method was recently compared with that used in this study, by Rutgers et al. [22]. The singlebreath method yielded higher values than the tidal breathing method, especially at higher NO concentrations, i.e. the difference between healthy controls and asthmatics becomes greater. The conclusion from the study was that the methods are not interchangeable, but that both methods could be used to measure differences between groups.

The total amount of $\mathrm{NO}$ exhaled in 1 min (NO output) was measured instead of using the concentration of NO, as the concentration is largely dependent on the exhalation flow rate. SiLKOFF et al. [23] have also shown that increased flow rate increases the amount of exhaled NO to some extent, whereas the NO concentration is evidently decreased. The NO output in the current study was in the range of those of previous studies using a similar method $[22,24,25]$.

The classification of the subjects as "gassed" or "ungassed" was based on information from the questionnaire. The workers at the mill had been concerned about the health effects of ozone; hence, the answers to the questionnaire may have tended to be biased. However, the exposure classification could not have been biased in relation to the outcome of interest, i.e. the NO levels. It is possible that exposed workers with respiratory symptoms might tend to over-report their experience of ozone gassings; however, this could not explain the present results, as no relationship could be seen between NO levels and respiratory symptoms

It is well established that acute ozone exposure elicits both nasal and more distal inflammation in the airways [10, 26]. Elevated levels of exhaled NO were associated with reported ozone gassings but not with respiratory symptoms or spirometric performances. Since the gassings preceded the investigation by months or even years, it is reasonable to hypothesize that the elevated NO levels must be a result of chronic airway inflammation. The limited data on chronic ozone exposure in humans describe inflammation in the distal part of the lung in the periacinar region. 
Table 4. - Variables included in a multiple linear regression model with nitric oxide output as the dependent variable

\begin{tabular}{lccc}
\hline Variable & Estimate & SEM & p-value \\
\hline Intercept (a) & 3.56 & 0.42 & 0.0001 \\
Age yrs (b) & 0.01 & 0.01 & 0.35 \\
Smoking* (c) & 0.13 & 0.14 & 0.35 \\
Sex $^{+}$(d) & 0.20 & 0.19 & 0.29 \\
$\begin{array}{l}\text { Atopy } \\
\text { Reported chlorine dioxide }\end{array}$ & -0.19 & 0.14 & 0.19 \\
$\begin{array}{l}\text { peaks (f) } \\
\text { Reported ozone peaks }\end{array}$ & 0.16 & 0.14 & 0.30 \\
Exposed $^{\S}$ (h) & 0.42 & 0.17 & 0.016 \\
\hline
\end{tabular}

Data are presented as log transformed values; $\mathrm{NO}$ output $=\mathrm{a}+$ $(\mathrm{b} \times$ age $)+(\mathrm{c} \times$ smoking $)+(\mathrm{d} \times$ sex $)+($ e $\times$ atopy $)+\left(\mathrm{ClO}_{2}^{-}\right.$peaks $)$ $+(\mathrm{g} \times$ ozone peaks $)+(\mathrm{h} \times$ exposed $)$ where $\mathrm{a}-\mathrm{h}$ are constants. $*$ : $0=$ never smokers/exsmokers, $1=$ current smokers; ${ }^{+}: 1=$ males, $0=$ females; ${ }^{\#}: 1=$ atopy (positive Phadiatope ${ }^{\mathrm{TM}}$ ), $0=$ no atopy; ${ }^{\S}$ : $1=$ yes, $0=$ no.

Theoretically, such pathological changes would give rise to few symptoms and limited spirometric decrements.

Although the exposed subjects had impaired FEV1 it is impossible to say whether this is an effect of gassings of ozone or chlorine dioxide. A decreased $\mathrm{FEV} 1 / \mathrm{FVC}$ ratio among gassed pulp workers has been described in other studies $[5,6]$.

In conclusion, the present study indicates an association between ozone gassing as reported and nitric oxide levels in exhaled air. The increased nitric oxide output among the exposed subjects reporting gassing events may indicate that sustained airway inflammation was present. Further studies are needed to evaluate the origin of the increased exhaled nitric oxide and the extent to which nitric oxide concentration can be used for biological monitoring of respiratory health effects in occupationally exposed groups.

\section{References}

1. Barnes PJ, Kharitonov SA. Exhaled nitric oxide: a new lung function test. Thorax 1996; 51: 233-237.

2. Alving K, Weitzberg E, Lundberg JM. Increased amount of nitric oxide in exhaled air of asthmatics. Eur Respir $J$ 1993; 6: 1368-1370.

3. de Gouw HWFM, Grünberg K, Schot R, Kroes ACM, Dick EC, Sterk PJ. Relationship between exhaled nitric oxide and airway hyperresponsiveness following experimental rhinovirus infection in asthmatic subjects. Eur Respir J 1998; 11: 126-132.

4. Lundberg JON. Airbone nitric oxide: Inflammatory marker and acrocrine messenger in man. Acta Phys Scand 1996; 157: (Suppl 633).

5. Kennedy SM, Enarson DA, Janssen RG, Chan-Yeung M. Lung health consequences of reported accidental chlorine gas exposures among pulp mill workers. Am Rev Respir Dis 1991; 143: 74-79.

6. Henneberger PK, Ferris BG, Sheche PR. Accidental gassing incidents and the pulmonary function of pulpmill workers. Am Rev Respir Dis 1993; 148: 63-67.

7. Henneberger PK, Lax MB, Ferris BG. Decrements in spirometry values associated with chlorine gassing events and pulp millwork. Am J Respir Crit Care Med 1996; 153: 225-231.

8. Torén K, Hagberg S, Westberg H. Health effects of working in pulp and paper mills: exposure, obstructive airways diseases, hypersensitivity reactions, and cardiovascular diseases. Am J Ind Med 1996; 29: 111-122.

9. Torén K, Blanc P. The history of pulp and paper bleaching: respiratory health effects. Lancet 1997; 349: 1316-1318.

10. Krishna MT, Mudway I, Kelly FJ, Frew AJ, Holgate ST. Ozone, airways and allergic disease. Clin Exp Allergy 1995; 25: 1150-1158.

11. Laskin DL, Pendino KJ, Punjabi CJ, Rodriguez del Valle M, Laskin JD. Pulmonary and hepatic effects of inhaled ozone in rats. Environ Health Perspect 1994; 102 (Suppl. 10): 61-64.

12. Adcock IM, Brown CR, Kwon O, Barnes PJ. Oxidative stress induces NF $\kappa$ B DNA binding and inducible NOS mRNA in human epithelial cells. Biochem Biophys Res Comm 1994; 199: 1518-1524.

13. Torén K, Järvholm B, Sällsten G, Thiringer G. Respiratory symptoms and asthma among workers exposed to paper dust: A cohort study. Am J Ind Med 1994; 26: 489496.

14. Olin A-C, Hellgren J, Karlsson G, Ljungkvist G, Nolkrantz K, Torén K. Nasal nitric oxide and its relationship to nasal symptoms, smoking and nasal nitrate. Rhinology 1998; 36: 117-121.

15. Sterk PJ, Fabbri LM, Quanjer PH, et al. Airway responsiveness; Standardized challenge testing with pharmacological, physical and sensititizing stimuli in adults. Eur Respir J 1993; 6 (Suppl. 16): 53-83.

16. Berglund E, Birath B, Bjure J, et al. Spirometric studies in normal subjects. III. Static lung volumes and maximum voluntary ventilation with a note of physical fitness. Acta Med Scand 1963; 173: 185-191.

17. Matricardi PM, Nisini R, Pizzolo JG, d'Amelio R. The use of Phadiatop in mass-screening programmes of inhalant allergies: advantages and limitations. Clin Exp Allergy 1990; 20: 151-155.

18. Kimberley B, Nejadnik B, Giraud GD, Holden WE. Nasal contribution to exhaled nitric oxide at rest and during breathholding in humans. Am J Respir Crit Care Med 1996; 153: 829-836.

19. Graham D, Henderson F, House D. Neutrofil influx measured in nasal lavages of humans exposed to ozone. Arch Environ Health 1988; 43: 228-233.

20. Balmes J. The role of ozone exposure in the epidemiology of asthma. Environ Health Perspect 1993; 101 (Suppl 4), 219-224.

21. Kharitonov S, Alving K, Barnes P. Exhaled and nasal nitric oxide measurements: recommendations. Eur Respir $J$ 1997; 10: 1683-1693.

22. Rutgers SR, Meijer RJ, Kerstjens HAM, van der Mark ThW, Köeter GH, Postma DS. Nitric oxide measured with single breath and tidal breathing methods in asthma and COPD. Eur Respir J 1998; 12: 816-819.

23. Silkoff PE, McClean PA, Slutsky AS, et al. Marked flowdependence of exhaled nitric oxide using a new technique to exclude nasal nitric oxide. Am J Respir Crit Care Med 1997; 155: 260-267.

24. Cremona G, Higenbottam TW, Mayoral V, et al. Elevated exhaled nitric oxide in patients with hepatopulmonary syndrome. Eur Respir J 1995; 8: 1883-1885.

25. Borland C, Cox Y, Higenbottam T. Measurements of exhaled nitric oxide in man. Thorax 1993; 48: 11601162.

26. Graham DE, Koren HS. Biomarkers of inflammation in ozone-exposed humans. Comparison of the nasal and bronchoalveolar lavage. Am Rev Respir Dis 1990; 142: $152-156$. 